\title{
On Marketing Strategies of Uniqlo: An Analysis of Online and Offline Integration
}

\author{
Wenshan Li \\ Business School, Lingnan Normal University, Zhanjiang, Guangzhou, China \\ E-mail: 843071068@qq.com \\ An-Shin Shia (Corresponding author) \\ Business School, Lingnan Normal University, Zhanjiang, Guangzhou, China \\ E-mail: 18875991570@qq.com
}

\begin{abstract}
Kemo Badiane
Nanfang College of Sun Yat-Sen University, 882, Wenquan Avenue, Gungzhou, China

E-mail: didibadiane@gmail.com
\end{abstract}

Received: September 22, 2020 Accepted: December 12, 2020 Published: December 18, 2020

doi:10.5296/csbm.v7i2.17676 URL: https://doi.org/10.5296/csbm.v7i2.17676

\begin{abstract}
The purpose of this study is to examine the difficulties of products out-of-sync, price conflict, serious lack of sales flow, two-way traffic flow difficulties and advantages in the process of online and offline integration. This paper analyzes the marketing strategies of online and offline integration of Uniqlo through literature review, case study, participant observation and SWOT analysis. Finally, the paper summarizes some online and offline marketing strategies which are suitable for traditional clothing retail businesses, and then provides references for the transformation of these enterprises. Theoretical implications of the findings are discussed, and the limitations of the study presented.
\end{abstract}

Keywords: Online and offline, Marketing strategy, Integration, Uniqlo

\section{Introduction}

Up to June 2019, the number of Internet users in China had hit 854 million and 639 million consumers are using the Internet for shopping. The trend of online shopping is becoming 
more and more obvious (China Internet Network Information Center, 2019; Jun \& Jaafar, 2011). In 2019, China's online retail sales reached 7.32 trillion Yuan with a year-on-year growth of $16.8 \%$. According to the data of the Ministry of Commerce in November 2019, China's online retail sales exceeded 870 billion Yuan (Central Radio Website, 2019). The change of consumers' consumption habits makes enterprises change their marketing strategies and conform to the trend. It is urgent for traditional clothing retailers to integrate online and

offline by adjusting their marketing strategies.

With the change of the times, many smart enterprises have strengthened their business development network, established brand sales portals of complete product series, and many niche clothing brands have open their stores on Taobao.com, JD.com, VIPs and other platforms (Jing Daily, 2020). Small-batch retail also entered micro-stores and other low-cost platforms. Through literature survey, case study and participant observation, this paper analyzes the integration of the online and offline environment and the situation of individual enterprises to achieve the following objectives:

- Solve online and offline product and price conflicts

- Identify the problem of online and offline two-way flow difficulties.

- Study the problem that the advantages are still not obvious after trying online and offline business.

\section{Company Profile and Sales' Status}

\subsection{Uniqlo}

Uniqlo Co., Ltd. is owned by the fast retailing group, which also owns brands such as GU and Theory. In 1949, 'the Japanese designer, manufacturer and retailer' (Schulz-Müllensiefen \& Stöckmann, 2016) started its own business and began selling clothes. Clothing will be leisure, fashion, occupation, sports and other styles of mutual integration. Uniqlo sells clothes as well as underwear, shoes, socks and hats, office wear, hijabs and son on (Naho, 2019). In April 2011, Uniqlo launched an online flagship store, which is a parallel between offline and online. From a small shop, it is selling now suits to its present 2,196 stores.

Table 1. Statistics of Uniqlo's Number of Stores in the Fiscal Year. Unit: Shop

\begin{tabular}{llllll}
\hline & 2015 & 2016 & 2017 & 2018 & 2019 \\
\hline $\begin{array}{l}\text { Uniqlo Japan } \\
\text { Uniqlo }\end{array}$ & 841 & 837 & 831 & 827 & 817 \\
Overseas & 798 & 958 & 1089 & 1241 & 1379 \\
\hline
\end{tabular}

Data Source: Fast Retailing Co., Ltd, 2020. 


\subsection{Overall Sales}

In recent years, Uniqlo has expanded in cities across all lines to form scale. Uniqlo's rapid growth is largely due to the rise of e-commerce. As can be seen from the following table, since Uniqlo started its online business, the annual sales volume of Uniqlo has shown a trend of growth due to the change in the consumption mode of the public.

Table 2. Uniqlo Fiscal Year Sales Statistics. Unit: One Million Yen

\begin{tabular}{llllll}
\hline & 2015 & 2016 & 2017 & 2018 & 2019 \\
\hline $\begin{array}{l}\text { Uniqlo Japan } \\
\begin{array}{l}\text { Uniqlo } \\
\text { overseas }\end{array}\end{array}$ & 780,139 & 799,817 & 810,734 & 846,778 & 872,957 \\
\hline
\end{tabular}

Data Source: Fast Retailing Co., Ltd, 2020

\section{Application Status and Current Situation of Internet Marketing}

\subsection{The Application Status of Internet Marketing in China and Abroad}

Most countries in the world have entered the period of Internet marketing. The Internet got its start in the United States some fifty years ago and the Internet marketing momentum is relatively strong. The United States supports the legal system to improve accordingly. The United Kingdom is the largest online shopping market in Europe (Asić, Kilibarda, \& Kaurin, 2019), and the British e-commerce market keeps growing by more than 10\% (Wang, 2017). Although Japan started later than the United States, it has a more mature Internet market.

Internet marketing has become a major trend (Sridevil \& Kumar, 2015), and the transformation of domestic traditional enterprises is inevitable. Developed countries are more mature in their development, providing a new breakthrough point for the transformation of domestic traditional enterprises, which prompts domestic traditional enterprises to learn from foreign enterprises excellent marketing strategies (He \& Wang, 2010).

The Chinese government has formulated special policies in the areas of e-commerce growth (Yue, 2017), online management and the flow of goods, cost reduction, growth benefits and efficiency improvement. E-commerce giants continue to expand offline stores and extend the value of online goods through physical stores. Wang Bingwen (2017) summarized that one of the motivations for online and offline integration is the macro environment, national policy support, logistics support, and payment convenience. Only by following the trend of the times, can enterprises not be eliminated (Wang, 2017). Wang Zhongbo (2012) pointed out the importance of online and offline integration. When enterprises conduct online business, they can use offline distribution system and after-sales service points to make up for the shortcomings of online business. Government support, network technology development, logistics support, convenient payment methods, etc., have strengthened the transformation of domestic enterprises. However, there is a lack of specific strategies for the integration of 
apparel retailers.

\subsection{Comparison of Network Marketing and Traditional Marketing}

\subsubsection{Advantages and Disadvantages of Network Marketing}

\subsubsection{Advantages of Network Marketing}

It is conducive to reduce the marketing cost of enterprises, reduce the cost of information transmission and save the cost of renting advertising sites, banners or other advertising tools (Zhao \& Tang, 2009). In network marketing, buyers and sellers through direct contact, the intermediate costs, the rental cost, and inventory will be saved.

It is conducive to extend the marketing space. Network marketing breaks the space and time limit, which the traditional marketing cannot replace. Marketing information spreads rapidly in the network space (Gabrielsson \& Kirpalani, 2004) and greatly improves the efficiency of the information dissemination. In addition, the network marketing breaks the geographical limit, and on-line customer direct contact anywhere.

It is beneficial for enterprises to provide personalized needs for consumers. Customers use network channels to produce a large amount of data for the enterprise. Through the data, the enterprise can understand the attitude of the customer and make timely response to provide personalized products or services for the customer. Understanding customers also leads to a better relationship management (Shanks, Jagielska, \& Jayaganesh, 2009).

To provide more convenient and independent consumption methods for customers. Nowadays, more and more consumers prefer to shop online. Online shopping can not only save the time to shop around and buy more cost-effective products, but also can be independent from the influence of the promoters.

\subsubsection{Disadvantages of Network Marketing}

Lack of experience, reality and trust. What network marketing presents generally is picture, video, sound or text, but can't touch the real things (Hao, 2011). And consumers always hesitate when shopping, they are concerned about fraud or product quality issues.

Risks to customers. In the network, we always notice the product picture or a few text explanations. It is difficult to judge the quality of the product. Consumers are prone to misjudge before purchasing goods leading to negative comments or complaints, which can easily affect the credibility of enterprises.

\subsubsection{Advantages and Disadvantages of Traditional Marketing Methods}

\subsection{Advantages of Traditional Marketing Methods}

Customers can directly touch the real product/object and directly experience the product or service, which can greatly reduce the risk-based purchase of goods (Bloch, 1982). In addition, the on-site explanation of promoters can stimulate consumers' desire to purchase, and at the same time, the after-sales service can also be better guaranteed (Rahman \& Chattopadhyay, 2015) 


\section{Macrothink}

Case Studies in Business and Management

ISSN 2333-3324

2020, Vol. 7, No. 2

For some people, shopping becomes a kind of enjoyment and fashion, online shopping cannot be replaced. Shopping can feel the fun of chatting, experiencing a comfortable and enjoying leisure life. There is no substitute for the experience of online shopping.

\subsection{Disadvantages of Traditional Marketing Methods}

In the process of commodity circulation, the products from the manufacturer to the consumer through the dealer greatly increase the cost of goods which leads to its competitive pricing advantage (O'Donnell, Gilmore, Carson, \& Cummins Darryl, 2002).

The traditional marketing method is limited by time and space, and the convenience of consumers to buy commodities is affected (Schubert \& Selz, 1999); so they cannot buy commodities anytime and anywhere. Moreover, limited to the region, the advertising effect is not obvious.

\subsection{The Integration of Internet Marketing Channel and Traditional Marketing Channel}

There is no strict distinction between traditional marketing and Internet marketing. Internet marketing cannot be separated from traditional marketing. Chen (2006) claimed that Internet marketing is derived from traditional marketing, while Traditional marketing provides a basic theoretical basis for Internet marketing. The relationship between the two marketing methods is complementary. To survive in this fast-changing world, the two types of marketing must be combined.

Table 3. Advantages and Disadvantages of Network and Traditional Marketing Methods

\begin{tabular}{|c|c|c|}
\hline & Internet Marketing & Traditional Marketing \\
\hline \multirow[t]{4}{*}{ Advantages } & $\begin{array}{l}\text { Help reduce the cost of the } \\
\text { enterprise. }\end{array}$ & Reduce the risk of consumer purchase. \\
\hline & $\begin{array}{l}\text { Help extend the marketing } \\
\text { space. }\end{array}$ & $\begin{array}{l}\text { Stimulate the desire of consumers to buy, } \\
\text { at the same time get better protection } \\
\text { after-sales. }\end{array}$ \\
\hline & $\begin{array}{l}\text { Help provide consumers with } \\
\text { personalized demand. }\end{array}$ & $\begin{array}{l}\text { For some people, online shopping is a kind } \\
\text { of enjoyment and cannot be replaced. }\end{array}$ \\
\hline & $\begin{array}{l}\text { Provide convenient } \\
\text { consumption ways to the } \\
\text { customer. }\end{array}$ & $\begin{array}{l}\text { In the process of commodity circulation, } \\
\text { the price advantage of dealers is not } \\
\text { obvious. }\end{array}$ \\
\hline \multirow[t]{2}{*}{ Disadvantages } & $\begin{array}{l}\text { Lack of experience, realism } \\
\text { and trust. }\end{array}$ & $\begin{array}{l}\text { Traditional marketing is limited by time } \\
\text { and space }\end{array}$ \\
\hline & $\begin{array}{l}\text { Easy to generate customer } \\
\text { risk. }\end{array}$ & The ads aren't obvious. \\
\hline
\end{tabular}




\section{Macrothink}

\section{Methodology}

\subsection{Qualitative Research}

\subsubsection{Literature Survey}

From November 2019 to April 2020, a large amount of Internet information was searched and collected on the Internet to obtain the basis needed by this research.

\subsubsection{Case Analysis}

From December 2019 to April 2020, a case study was conducted to analyze Uniqlo's current online and offline marketing strategies in order to provide reference for traditional apparel enterprises.

\subsubsection{Participant Observation}

From January 2019 to July 2019, the researcher worked as an intern in Zhanjiang Uniqlo Wanda Plaza in Zhanjiang City, Guangdong Province, China. The relevant materials are summarized to come into contact with to support this paper.

\subsubsection{Case Selection}

Uniqlo is selected as an example of a research article. On the one hand, Uniqlo adopts an unconventional online and offline mode, which selects store physical locations by using data to increase brick-and-mortar stores. Moreover, it provides self-pick-up services to attract customers to physical stores. On the other hand, Uniqlo trains offline staff to introduce customers to a variety of purchasing channels. Uniqlo's online and offline channels promote each other (Mall China, 2015; Hu, Song, \& Ren, 2016), and the transformation is successful, so the other enterprises should learn from them.

\section{Analysis of the Company's Online and Offline Integrated Marketing}

\subsection{SWOT Analysis of Uniqlo}

\subsubsection{The Strengths of Uniqlo}

Distinct brand positioning and high-quality brand image. Customers' love and trust for the brand expand their influence in the market. A good corporate image is conducive to cultivating loyal customers, and the influence of corporate brand and excellent corporate image bring sufficient flow in online channels (Mirza, Verma, Kee, Awatif, Qistina, Aswadi, 2020; The Economist, 2019).

The scope of physical stores is large and dense. Physical stores provide offline experience services for consumers. Consumers can feel the texture of commodities, try on them, solve their doubts directly, and enhance their trust existing in enterprises. Mortar-brick-stores not only make up for online deficiencies, but also make consumers feel confident to buy goods over the internet (Ryall, 2019).

High productivity and strong quality control. To develop online pipelines, the output and quality of products must be kept up to ensure adequate supply. High output can provide 
adequate supply for online pipelines and guarantee product quality, which is conducive to the integration of online and offline enterprises (Martin, 2019).

Strong cost control ability. It is easy for consumers to compare commodity prices online, and the price is also a very important factor. In the competition with similar products of competitors, the cost advantage is the embodiment of competitiveness, which is conducive to online development.

Advantages of the mode of integrating stores and warehouses. Stores are also warehouses, which greatly reduce inventory and labor costs, and greatly improve service efficiency when providing services such as self-pick-up and delivery of online orders.

Attach importance to talents. The headquarter recruits and develops college graduates every year to inject fresh blood into the company. We can not only transport talents to stores, but also develop and transport talents to online channels to ensure the smooth operation of online business.

\subsubsection{The Weaknesses of Uniqlo}

There will be conflicts for consumers. Due to the convenience of online shopping and the limitation of time and space, there is an imbalance between online and offline traffic to a certain extent, which will squeeze the development space offline.

The investment cost of talent training is high, and the problem of brain drain is serious. The development of online channels will increase the demand for talents, and there is a risk of the shortage of talents and skills.

\subsubsection{The Opportunities}

The government's policies on e-commerce are improving the performance of e-commerce, standardizing online transaction rules, and providing support to enterprises in the development of online businesses (Wang, Wang, \& Lee, 2017), so as to create a healthy development environment for enterprise transformation and promote the integration of online and offline enterprises.

E-commerce is developing rapidly, and online forms are becoming more and more diverse (Efendioglu \& Yip, 2004), such as enterprise Apps, Tmall flagship store, internal purchase link of official account and handheld flagship store of WeChat applet, etc., which is beneficial for enterprises to contact customers at a variety of consumer contact points and expand customer groups. With the rapid and rising economic environment, consumers know that their income increases and their consumption power increases providing a good development environment for Uniqlo.

The rise of the Internet. The rapid growth of the number of Internet users, the transformation of the mode of mass consumption (Wang, 2012), and the increasing proportion of online consumption provide a strong condition for enterprises to transform and develop towards the direction of online and offline integration. 


\subsubsection{The Threats}

Fierce competition among peers. In addition to ZARA, GAP, H\&M and other large enterprises, there are also emerging clothing enterprises such as UR and ONLY. This year, a large number of potential competitors have also entered the market. In China, companies such as la Chapelle, Semir and LT are also rising to take part in market segmentation.

Trust problems are more likely to arise in the online environment. China is the largest market for goods, and the online market is even larger (Zouria \& Udanoh, 2020). Shanzhai products are circulating in the market and affect the corporate image to a certain extent.

The development of e-commerce is changing rapidly, and the trading environment of e-commerce is changing all the time. There are still many unknowns. These laws were made long time ago, and laws that can match the development speed of e-commerce still need to be improved to achieve competitive advantage (Dobbs, 2014).

Table 4. SWOT Analysis Model of Uniqlo's Online and Offline Integration

\begin{tabular}{|c|c|}
\hline Strengths & Weaknesses \\
\hline $\begin{array}{l}\text { Distinctive brand positioning and high-quality brand } \\
\text { image. }\end{array}$ & $\begin{array}{l}\text { Competition for consumers. } \\
\text { High cost of personnel training. }\end{array}$ \\
\hline \multicolumn{2}{|l|}{ The physical stores are large and dense. } \\
\hline \multicolumn{2}{|l|}{$\begin{array}{l}\text { High production capacity and strong quality control } \\
\text { ability. }\end{array}$} \\
\hline \multicolumn{2}{|l|}{ Strong cost control ability. } \\
\hline \multicolumn{2}{|l|}{ Store and warehouse as a whole mode advantage. } \\
\hline \multicolumn{2}{|l|}{ Value talent. } \\
\hline Opportunities & Threats \\
\hline Government policy support. & The competition is fierce. \\
\hline $\begin{array}{l}\text { With the rapid development of e-commerce, online } \\
\text { forms are becoming more and more diverse. }\end{array}$ & $\begin{array}{l}\text { Trust issues are more likely to } \\
\text { arise in a network environment. }\end{array}$ \\
\hline $\begin{array}{l}\text { The world economy is relatively stable and China's } \\
\text { economy is developing rapidly. }\end{array}$ & $\begin{array}{l}\text { Laws matching the pace of } \\
\text { e-commerce development are }\end{array}$ \\
\hline Changes in the way people consume. & imperfect. \\
\hline
\end{tabular}

\subsection{Favorable Sufficient Conditions}

The advantages of online and offline integration are obvious. Uniqlo has accumulated a number of favorable conditions: distinct style, high-quality brand image, wide store coverage, significant position in the industry (Burt \& Carralero-Encinas, 2000), strong online channel to attract traffic; perfect quality inspection system, strict assurance commodity quality, cost 
control and talented person troop construction are also key factors. Internal advantages ensure the feasibility of online and offline integration.

The opportunity to integrate online and offline is rare. The external opportunities of the company greatly affect the feasibility of the project. The government carries on the legal standard to the transaction environment, creates the healthy and powerful environment for the enterprise; increased public spending power makes the project more feasible.

\subsection{Optimization Game Perfection}

Analyze and improve weaknesses. The company can improve the feasibility of the project by reversing the disadvantages. First of all, the main direction of online and offline is mutual assistance. For example, offline promotion of Apps installation, issuance of entity special coupons, and realization of traffic interflow; improve the enterprise salary system, take into account the spiritual care and provide talents for constructing online platforms.

Look at external threats and take action. If no action is taken to reduce its impact on the progress of the project, the project will become less feasible. We must pay attention to the dynamics of competitors, such as H\&M and ZARA and adjust our strategies. Use special materials or special marks as far as possible so that consumers are easy to identify and suppress goods. In the early days of development, avoid areas where law is unclear.

\section{The Company's Online and Offline Marketing Integration Strategy}

\subsection{Product}

Some enterprises have different delivery time for all kinds of products online and offline, resulting in online and offline conflicts. Uniqlo adopts the product strategy which is same quality and new products launched at the same time (Sarker, Lipol, \& Saeed, 2020). Product quantification is conducive to obtaining cost advantages. When there are demands both online and offline, offline and online synchronization is helpful for providing a variety of consumption channels to meet consumer demand. As Uniqlo says: "the new retail is where the consumer is, where we are, there is no constraint online or offline." Uniqlo Apps not only shoulder the sales task, but also aims at improving the product exposure, launching products synchronously and expanding the influence of products.

In the daily morning meeting, the store manager stressed to staff when the new products were launched: all the staff mainly push the new products in the display table. If the products are sold out, please timely check the inventory for the customers in the online flagship store.

\subsection{Price}

The practice of the same quality, same price will promote online and offline integration. As consumers are used to comparing prices of the same products when shopping online. So physical stores can also participate in the price comparison of the whole network if applying same price both online and offline. Moreover, consumers can easily compare prices online and in physical stores, which prolongs the time for making decisions and weakens consumers' impulse to spend. The unified price of online and physical stores can reduce the obstacle of 
customers' purchase cognition, maintain customers' impulse of consumption, and improve the sales conversion rate without the process of price comparison.

During the $\mathrm{O} 2 \mathrm{O}$ business training, the head of the $\mathrm{O} 2 \mathrm{O}$ business of the store said: our integration of online and offline is very good, the online and offline prices are the same, there is no pipeline conflict. When placing an order for customers in the store, be sure to explain clearly to customers that the online and offline commodity prices are the same, guide customers to place an order online and improve the 020- business contribution rate to the store.

\subsection{Promotion}

Uniqlo uses promotional coupons and staggered promotions to facilitate a two-way flow of traffic between online and offline. Use promotional coupons to lure each other. Guide customers to follow the Uniqlo official account, download the Uniqlo Apps or open the Uniqlo WeChat flagship store to get coupons, and guide customers to use online channels. According to the geographical location of users, the geographical location of nearby stores is placed in the App or flagship store on the palm, and the coupons that are only available in the store are specially set up to facilitate offline drainage. Use stagger promotion time to drain each other. If customers miss the offline discount, they can buy it in the store and lead the offline customers online.

During the Spring Festival, when the deputy store manager gave staff training on Spring Festival activities, he repeatedly stressed that he would guide customers into the online shopping platform of Uniqlo to receive coupons which were only available in physical stores.

\subsection{Place}

\subsubsection{Stick to Direct Pipelines}

The company directly manages each design, purchase, sales and so on, and strengthens the operation control. In the process of offline integration, Uniqlo still adheres to this pipeline model, mainly because Uniqlo's direct-sale pipeline has prominent advantages over other franchised apparel enterprises, such as controlling the online price, highlighting the cost advantage, showing the brand strength, establishing the corporate image, and facilitating the understanding of market information.

\subsubsection{Stick to Physical Stores}

When trying online business, the existence of offline physical stores is also very important, with a contribution rate of $0.55 \%$. Online business can facilitate consumers' consumption, and offline business can provide them with fitting and experience (Chen, $\mathrm{Qu}$, Wang, \& Pan, 2008). Uniqlo choses to expand its stores quickly. Consumers can quickly touch goods in offline stores, feel the quality of goods or try them on.

During the induction training, the colleague in charge of the training introduced the company, saying: Uniqlo is mainly a direct chain store, which is under the unified management of the headquarters. Therefore, the company has strict control over product quality, high 
requirements on service quality and a good brand image in the minds of consumers.

\subsection{Service}

The service quality of e-commerce platform can directly or indirectly promote the co-creation behavior of customers' brands, and the service quality also makes customers more willing to participate in the co-creation of brands. Therefore, Uniqlo attaches great importance to value-added services of commodities, whether online or offline, and realizes the transformation of consumers from paying attention to price to paying attention to value (Yin, Zhao, Chen, \& Li, 2019).

In order to provide customers more intimate services, online and offline goods can be modified in stores. Offline stores provide online ordering, open self-pick-up channel, and realize quick pick-up of goods in stores. Now, it also provides self-pick-up service in physical stores across different regions. Providing digital poster service, the store can be connected to WIFI, scan the store data poster, understand the clothing matching and real-time inventory.

Uniqlo not only has high requirements on service, but also has strict requirements on the service quality of store staff. Six principles and four service terms must be memorized in the morning meeting every day and must be carefully implemented in the work. Therefore, Uniqlo service is worthy of learning by other enterprises.

\subsection{Information}

The change of consumer consumption mode enables enterprises to obtain more data, and enterprises that know how to enhance their own competitiveness through information construction have more advantages and are data driven. Uniqlo attaches great importance to the use of information and chooses the informatization strategy, which makes Uniqlo stands out from many competitors.

Establish the data model to grasp the pace of the shop and help site selection of new stores through the analysis of the data. According to the data collected by various platforms, we will firmly grasp each consumption channel, accurately find the stimulus points of consumers' shopping, automatically push products, and improve the conversion rate. During data analysis, data from physical stores and various platforms will be sent to the factories authorized for production by relying on cloud computing to filter data, so as to effectively reduce inventory costs (Li \& Lin, 2019).

\section{Conclusions and limitations}

\subsection{Conclusion}

With the rapid rise of online shopping, only when traditional enterprises give full play to the advantages of physical stores and take into account the development of online business at the same time, can they complement each other and not be eliminated by the market. The above analysis of Uniqlo strategy achieves the purpose of the research, and the following conclusions are drawn:

(1) Solve the problem of channel conflicts through online products and price strategies of the 
same products with the same quality and same price.

(2) Conduct online and offline mutual drainage through promotional activities.

(3) Make use of the advantages of direct chain stores, integrate online and offline platform data, exploit customers' demands for products or services by making use of informatization, and adopt convenient and humanized service strategies to realize the maximum value of online and offline integration.

\subsection{Limitations}

As the research period from November 2019 to April 2020 is short, time and research capacity are limited, the following limitations are generated in the research process:

(1) Uniqlo's strategy is not fully suitable for the actual situation of all enterprises. In this research, only a single retail store was involved in our study, with limited time, and other retail businesses were not included in the comparative study.

(2) Although Internet marketing in the retail industry has been a growing area of interest over the past decade, there is no authoritative and reliable theoretical framework to support the transformation of traditional clothing retail brands. As a result, there is a lack of literature references in this study, which leads to research limitations.

(3) The information of the Internet environment is changing, and there are various types of online shopping platforms. Currently, the online and offline integration strategies of Uniqlo are analyzed, and the contents cannot fully reflect the changes brought by the environment.

\section{References}

Bloch. (1982). Involvement Beyond the Purchase Process: Conceptual Issues and Empirical Investigation. in NA - Advances in Consumer Research Volume 09, eds. Andrew Mitchell, Ann Abor, MI: Association for Consumer Research (pp. 413-417).

Burt, S., \& Carralero-Encinas, J. (2000). The role of store image in retail internationalization. International Marketing Review, 17(4-5), 433-453. https://doi.org/10.1108/0265133001 0339941

Central Radio Website. (2019). The Ministry of Commerce: During the Period of "Double Eleven" National Network Retail Sales More Than 870 Billion Yuan Year-on-year Growth of $26.7 \%$

Chen, C-Y. (2006). The comparison of structure differences between internet marketing and traditional marketing. International Journal of Management and Enterprise Development, 3(4). https://doi.org/10.1504/IJMED.2006.009088

Chen, C., Qu, H., Wang, M., \& Pan, Y. (2008). The Impact of O2O Offline Experience on Clothing Consumers' Purchase Intention. Journal of Beijing Institute of Fashion Technology (Natural Science Edition), 01, 15-16.

Dobbs, M. E. (2014). Guidelines for applying Porter's five forces framework: a set of industry analysis templates. Competitiveness Review: An International Business Journal, 24(1), 32-45. https://doi.org/10.1108/CR-06-2013-0059 


\section{Ml Macrothink}

Case Studies in Business and Management

ISSN 2333-3324

2020, Vol. 7, No. 2

Efendioglu, A. M., \& Yip, V. F. (2004). Chinese culture and e-commerce: an exploratory study, Interacting with Computers, 16(1), 45-62, https://doi.org/10.1016/j.intcom.2003.11.004

Fast retailing Co., ltd, Sales [EB/OL] (2020). https://www.fastretailing.com/eng/, 2020.03.01

Gabrielsson, M., \& Kirpalani, V. H. M. (2004). Born Globals: How to Reach New Business Space Rapidly. International Business Review, 13(5), 555-571. https://doi.org/10.1016/j. ibusrev.2004.03.005

Guo, J. G., Jaafar \& Noor, I. (2011). A Study on Consumers' Attitude towards Online Shopping in China. International Journal of Business and Social Science, 2(22).

Hao, W. (2011). Research on Network Marketing of Small and Medium-Sized Enterprises. 2011 International Conference on Management and Service Science, Wuhan, 2011, pp. 1-4. https://doi.org/10.1109/ICMSS.2011.5997944

He, C., \& Wang, J. (2010). Geographical agglomeration and co-agglomeration of foreign and domestic enterprises: a case study of Chinese manufacturing industries. Post-Communist Economies, 22(3), 323-343. https://doi.org/10.1080/14631377.2010.498682

Hu, X., Song, B., Ni, Y., Ren, Y., \& Li, R. (2016). The O2O Model-From Online/Offline to the $\mathrm{O} 2 \mathrm{O}$ Model. Business Trends in the Digital Era. Springer, Singapore. https://doi.org/10.1007/978-981-10-1079-8_10

Jing Daily (10 May 2020). Navigating Tmall: A Guide for Luxury. https://jingdaily.com/navigating-tmall-a-guide-for-luxury/

Li Bin, Lin Meixiang (2019). Research of the Application of Cloud Computing Technology in Electric Commerce Practice [A]. Proceedings of 2019 9th International Conference on Social Science and Education Research (SSER 2019) [C].2019

Martin, R. C. (2019). UNIQLO: The strategy behind the global Japanese fast fashion retail brand. $\quad$ Retrieved from https://martinroll.com/resources/articles/strategy/uniqlo-the-strategy-behind-the-global-japan ese-fast-fashion-retail-brand/.

Mirza, M., Verma, A., Kee, D., Mui, H., \& Aswadi, M. K. (2020). The Key Success Factors: A Case Study of UNIQLO. Journal of the Community Development in Asia, 3(2). https://doi.org/10.32535/jcda.v3i2.805

Naho, B. M. (2019). 5 Best UNIQLO products to buy. Retrieved from https://jw-webmagazine.com/what-you-should-buy-best-budget-fashion-retailer-uniqlo-16a18 $29740 \mathrm{~b} 5 /$

O'Donnell, A., Gilmore, A., Carson, D., \& Cummins, D. (2011). Competitive advantage in small to medium-sized enterprises. Journal of Strategic Marketing, 10(3), 205-223. https://doi.org/10.1080/09652540210151388

Rahman, A., \& Chattopadhyay, G. (2015). Long Term Warranty and After Sales Service. In: Long Term Warranty and After Sales Service. SpringerBriefs in Applied Sciences and Technology. Springer, Cham. https://doi.org/10.1007/978-3-319-16271-3_1

Ryall, J. (2019). The UNIQLO story: from a single store to a global fashion empire, with ambitions to be world's No 1 brand. Retrieved from https://www.scmp.com/lifestyle/fashion-beauty/article/3029602/uniqlo-story-single-store-glo bal-fashion-empire-ambitions. 
Sarker, T. R., Lipol, L. S., \& Saeed, A. A. (2020). Benchmarking Marketing and Business Strategy of UNIQLO to Start-up a Retail Shop in Bangladesh. European Journal of Business and Management, 12(2).

Schubert, P., \& Selz, D. (1999). Web assessment-measuring the effectiveness of electronic commerce sites going beyond traditional marketing paradigms. Proceedings of the 32nd Annual Hawaii International Conference on Systems Sciences. 1999. HICSS-32. Abstracts and CD-ROM of Full Papers, Maui, HI, USA. https://doi.org/10.1109/HICSS.1999.772941

Schulz-Müllensiefen, F., \& Stöckmann, A. (2016). Uniqlo: A Case Study on Creating Market Share with Affordable and Timeless Designs. Multinational Management. Springer, Cham. https://doi.org/10.1007/978-3-319-23012-2_12

Segers, R. T. (2016). Multinational Management: A Casebook on Asia's Global Market Leaders, Springer International Publishing AG Switzerland.

Shanks, G., Jagielska, I., \& Jayaganesh, M. (2009). A Framework for Understanding Customer Relationship Management Systems Benefits. Communications of the Association for Information Systems. https://doi.org/10.17705/1CAIS.02526

Sridevi, J., \& Kumar, K. S. (February 2015). Emerging Trends in Online Marketing. ICTACT Journal on Management Studies, 1(1).

The Economist. (2019). UNIQLO's founder plots a way to beat Zara and H\&M. Retrieved from https://www.economist.com/business/2019/02/09/uniqlos-founder-plots-a-way-tobeat-zara-and-h-and-m

Vasić, N., Kilibarda, M., \& Kaurin, T. (2019). The Influence of Online Shopping Determinants on Customer Satisfaction in the Serbian Market. Journal of Theoretical and Applied Electronic Commerce Research, 14(2). https://doi.org/10.4067/S0718-18762019000200107

Wang, B. (2017). Research on Online and Offline Integration of Modern Retail Industry. Anhui University of Finance and Economics.

Wang, S. S. (2012). China's Internet lexicon: Symbolic meaning and commoditization of Grass Mud Horse in the harmonious society. First Monday, 17(1). https://doi.org/10.5210/fm.v17i1.3758

Wang, Y., Wang, Y., \& Lee, S. H. (2017). The Effect of Cross-Border E-Commerce on China's International Trade: An Empirical Study Based on Transaction Cost Analysis. Sustainability, 9, 20-28. https://doi.org/10.3390/su9112028

Wang, Z. (2012). Research on Marketing Strategies to Improve the Performance of Online Extension of Traditional Retailers. Dongbei University of Finance and Economics.

Yue, H. (2017). National Report on E-commerce Development in China, Inclusive and Sustainable Industrial Development Working Paper Series WP 17. United Nations Industrial Development Organization.

Zhao, X., \& Tang, Q. (2009). Analysis and Strategy of the Chinese Logistics Cost Reduction. International Journal of Business and Management, 4(4). https://doi.org/10.5539/ijbm. v4n4p188

Zouria, A., \& Udanoh, M. U. (March 2020). Successful Internet Entrepreneurs: The Case of China. International Journal of Social Science Studies, 8(2). https://doi.org/10.11114/ijsss. v8i2.4659 


\section{Copyrights}

Copyright for this article is retained by the author(s), with first publication rights granted to the journal.

This is an open-access article distributed under the terms and conditions of the Creative Commons Attribution license (http://creativecommons.org/licenses/by/4.0/). 